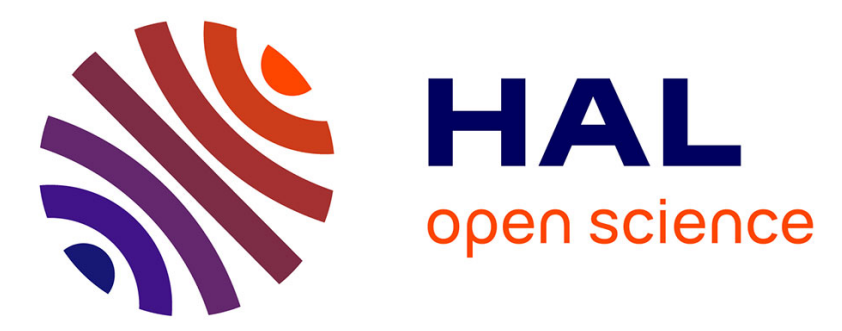

\title{
Childhood poverty and deprivation at the starting gate in France. Examples using Elfe survey
}

Bárbara Castillo Rico, Marion Leturcq, Lidia Panico

\section{To cite this version:}

Bárbara Castillo Rico, Marion Leturcq, Lidia Panico. Childhood poverty and deprivation at the starting gate in France. Examples using Elfe survey. Revue des politiques sociales et familiales, 2019, Understanding children's well-being: A political issue, 131-132, pp.35-49. hal-02470628

\section{HAL Id: hal-02470628 \\ https://hal.science/hal-02470628}

Submitted on 7 Feb 2020

HAL is a multi-disciplinary open access archive for the deposit and dissemination of scientific research documents, whether they are published or not. The documents may come from teaching and research institutions in France or abroad, or from public or private research centers.
L'archive ouverte pluridisciplinaire HAL, est destinée au dépôt et à la diffusion de documents scientifiques de niveau recherche, publiés ou non, émanant des établissements d'enseignement et de recherche français ou étrangers, des laboratoires publics ou privés. 


\title{
Childhood poverty and deprivation at the starting gate in France
}

\author{
Examples using Elfe survey
}

Barbara Castillo Rico Marion Leturcq* Lidia Panico*
Poverty is not uncommon among children growing up in developed countries. In France, in 2014, 19,8\% of children lived in households below the poverty line (HCFEA, 2018). Childhood poverty has been a long-standing concern for researchers and policymakers (as for example shown by recent policies introduced in France to reduce childhood poverty and inequalities), largely because of its impact on children's outcomes (Dahl and Lochner, 2012) and its long-term consequences for adult wellbeing (Duncan et al., 2012). While recent reports for France have provided a picture of childhood poverty for children of all ages (HCFEA, 2018; OIC, 2018), the literature focusing on early childhood remains limited. Yet this period of life is increasingly recognized as a crucial time to understand individual trajectories and populationlevel inequalities (Irwin et al., 2007). Starting in early 2011, the French Longitudinal Study from Childhood (the Étude Longitudinale française depuis I'enfance, Elfe) provides a unique opportunity to address a number of questions on the living conditions of children at the start of their lives, using a nationally representative sample of births in mainland France.

An interdisciplinary study such as Elfe is also able to explore childhood poverty as a multi-dimensional concept. Increasingly, researchers argue that financial poverty is not, on its own, a good indicator of the experience of deprivation, particularly for children (Fusco et al., 2011). As a result, multi-dimensional deprivation measures have been suggested as a tool to understand how economic wellbeing impacts individuals (Stiglitz et al., 2009), although these concepts have been applied less to children (Unicef, 2013), and in particular very young children. In this paper, we therefore propose to present a picture of poverty and multi-dimensional deprivation of children in France, around the time of their birth and during their first year of life, using an income poverty measure combined with a multiple deprivation approach. To do so, we adapt an approach used for adults to apply it to young children; this adaptation allows us to take account of children's specific needs. We then use regression techniques to highlight which population groups are most vulnerable to monetary poverty and to deprivation across several domains.

\section{Literature review \\ The importance of experiencing poverty in childhood}

A vast body of research has shown that the experience of child poverty has a clear impact on children's health and development, as well as long term consequences: poverty in childhood is linked to, for example, lower educational attainment, higher risk of unemployment, and continued to experience poverty in adulthood (Duncan and Magnuson, 2013; Duncan et al., 2012). Growing up in poverty has been shown to be associated with higher rates of mortality in adulthood (Case et al., 2005), as well as adult health outcomes such as asthma, diabetes, heart disease (Johnson and Shoeni, 2011), and obesity (Dong et al., 2004).

Why does experiencing poverty and deprivation matter for current and subsequent well-being? Arguably, in countries with strong safety nets and free or subsidised education and healthcare, poverty and deprivation should be moderated by access to modern welfare services and therefore have only a minor impact on children. Yet the link between poverty or deprivation and a range of child outcomes has been consistently established across countries, even those with strong welfare safety nets (Ermisch et al., 2012; Gallo et al., 2012). Mechanisms to explain the association between poverty and poor child and adult outcomes have included disadvantaged material

The ELFE survey is a joint project between Ined (Institut national d'études démographiques), Inserm (Institut national de la santé et de la recherche médicale), EFS (Établissement français du sang), Santé publique France, Insee (Institut national de la statistique et des études économiques), the Ministry of Health (DGS, direction générale de la santé), the Ministry of Ecological and Solidarity Transition (DGPR, direction générale de la prévention des risques), the Ministry of Solidarity and Health (Drees, direction de la recherche, des études, de l'évaluation et des statistiques), the Ministry of Culture (Deps, département des études, de la prospective et des statistiques), and the Cnaf (Caisse nationale des Allocations familiales), with the support of the Ministry of Research and Injep (Institut national de la jeunesse et de l'éducation populaire). As part of the Reconai platform, Elfe is financed through a State subvention managed by the Agence nationale de la recherche, through the Investissements d'Avenir program (ANR-11-EQPX-0038).

Revue des politiques sociales et familiales $n^{\circ} 131-132-2^{\text {nd }}$ et $3^{\text {rd }}$ quarters 2019

175 Understanding children's well-being: A political issue 
conditions, poorer housing, negative impacts on parenting and parents' own mental health (Conger et al., 2010; Esping-Andersen, 2008), as well as difficulties in accessing key services such as schooling and education. Furthermore, low incomes may have a direct impact on families' abilities to meet children's basic needs. For example, while in most developed countries the majority of households are able to buy enough food to sustain themselves, the quality of this food may decline when families experience financial constraints. In the European countries most affected by the current recession, daily nutritional intake and the consumption of nutritious food, such as fish and vegetables, has declined (Unicef, 2014). These debates have never been more salient than in the current context of economic instability. Children are widely acknowledged to be the group that suffers most from the current economic crisis, and more than other vulnerable populations such as the elderly (ibid.). The recession has impacted children through a steady deterioration in the situation of their families, mostly due to job loss, underemployment and public services cuts. It is therefore unsurprising that the 2014 Unicef Innocenti Report Card concluded that the Great Recession has been linked to a decline in children's well-being in developed countries (ibid.).

\section{How can we measure poverty in children?}

There are a number of ways to conceptualise and measure "poverty" in childhood. Many studies look at the proportion of children living in monetary poor households (usually defined as households whose incomes are less than 50\% or $60 \%$ of the median income). This indicator captures financial constraints. However, just looking at family income does not always reflect living conditions and well-being, especially for children (Unicef, 2013). This is both because income is not a reliable indicator of the resources available to the household (and, in particular, of resources distributed towards children), but also because, as shown by sociologists like Peter Townsend (1979) and economists like Amartya Sen (1999), poverty is about more than simply being unable to feed oneself, and non-financial dimensions of deprivation (such as social integration, participation in socially normative activities etc.) also matter.

The concepts of deprivation and in particular multi-domain deprivation have emerged to account for these criticisms. It is argued that these broad concepts better capture children's lived experience of poverty. For example, the Unicef childhood deprivation indicator considers children to be deprived when the household in which they live cannot afford at least four of nine items (i.e. being able to: pay rent, mortgage or utilities; keep the home adequately warm; face unexpected expenses; eat meat or protein regularly; take holidays; own a television; a washing machine; a car; a telephone). After years of improvements for most European countries, the proportion of materially deprived children remained constant at $7 \%$ to $8 \%$ between 2008 and 2012. It is also important to note that measurements of financial poverty and deprivation do not always capture the same children: children can live in monetary poor households but not be deprived because, for example, parents prioritize resources towards them, or thanks to support from extended families, communities or national programmes. Inversely, deprived children can live in non-poor households if parents are unable to manage resources or channel them towards their needs, or if, for example, the cost of acquiring goods and services is too high and not moderated by government programmes.

\section{What do we know about childhood poverty in France?}

The issue of childhood poverty is currently at the forefront of national policies in France. In October 2017, the government launched a national strategy to combat poverty and social exclusion, with a focus on early childhood. This led to a number of recent reports describing the living conditions of children in France today. These reports highlight that childhood poverty (i.e. households earning $60 \%$ or less of the median equivalised income) in continental France is higher than the poverty rate for the overall population (19,8\% versus $14 \%$ - HCFEA, 2018). In fact, while France compares relatively favourably with the rest of Europe in terms of overall monetary poverty (only the Netherlands has lower overall poverty rates), when we look at child poverty, the comparison with its neighbours is much less favourable (ibid.). In 2017, Eurostat statistics show that $16 \%$ of all adults (16 years and over) and $21,7 \%$ of children (under 16 ) are classed as income-poor in France, while in the European Union, 22,2\% of adults and $24 \%$ of children are poor ${ }^{(1)}$. In particular, children living with a single parent and households with a large number children are especially at risk. For these two groups, poverty rates in 2014 reached $40 \%$ (for single parent households with at least one dependent child; and for households with four co-residing children, at least one of whom is a dependent minor); these rates have been deteriorating since 2008 (ibid.).

\footnotetext{
(1) From https://www.strategie.gouv.fr/sites/strategie.gouv.fr/files/atoms/files/hcfea-note_synthese_-_pauvrete_et_familles_-5_juin.pdf.

Revue des politiques sociales et familiales $n^{\circ} 131-132-2^{\text {nd }}$ et $3^{\text {rd }}$ quarters 2019 
Two important gaps in the current data available for France include figures on deprivation, rather than just income, and data specific to young children, rather than aggregating children of all ages. In respect to the first point, data from EU-SILC paints a picture of material deprivation for children of all ages. They show that in 2016, about $12 \%$ of children living in France could be classed as deprived (see the above description of the Unicef indicator for details of the items used for these analyses), rising to nearly a third for children living with a single parent. However, these data are based on deprivation at the household level only and do not include child-specific items, leading to un-nuanced observations such as "children are poor because their parents are poor" (OIC, 2018). On the second point, to our knowledge no study focused specifically on the experience of poverty and deprivation in early childhood in France. This is problematic, as early childhood is increasingly recognised as a crucial period to understand individual trajectories and population-level inequalities (Irwin et al., 2007). At this important time, children's early experience of adverse living conditions and poverty can affect their health and development, not only when they are young (Dickerson and Popli, 2015; Pearce et al., 2013), but also in adulthood. The French literature focusing on early childhood remains limited, and often takes a cognitive and clinical perspective. However, starting in early 2011, the French Longitudinal Study from Childhood (Elfe) provides a unique opportunity to address a number of questions on the living conditions of French children at the start of their lives, using a recent and nationally representative sample of births in mainland France. In this paper, we propose a multi-domain deprivation approach to describe the living conditions of infants from birth and during their first year of life, as well as looking at standard indicators of financial poverty. We then use regression techniques to highlight which population groups are most at risk of which type of deprivation. The large, nationally representative sample and the rich nature of the study, tapping into different dimensions of children's lives, allows us to describe relatively nuanced situations for an age group that has to date received little attention in France.

\section{The Étude longitudinale française depuis I'enfance}

Elfe (Étude longitudinale française depuis l'enfance) is France's first multidisciplinary, large scale longitudinal cohort study based on a population sample (Charles et al., 2011). It aims to follow over 18,000 children born in
France in 2011 from birth to adulthood. The study explores how socio-economic, environmental and family environments in early life affect children's health, development and socialization, and, ultimately, their subsequent adult situation. The Elfe sampling structure is based on two simultaneous levels, with an independent selection of a representative sample of hospitals featuring a maternity ward in continental France (stratified according to size), and a selection of four periods of the year to cover the four seasons (twenty five days in total: four days in April, six in June/July, seven in September/October, eight in November/December). In 2011, all babies born at a selected maternity unit during one of the chosen inclusion periods were eligible to participate in the study (Juillard, 2016). Three hundred forty-nine maternity wards (both public and private) represent the five hundred and forty-four hospitals with a maternity ward on the French mainland territory (excluding overseas territories). 18329 infants were included in the initial sample. Eligible mothers had to satisfy the following inclusion characteristics: their babies were born at or after thirty-three weeks' gestation (2), both parents were at least 18 years old at the time of the birth, and only singleton and twin births were included.

The first wave of data collection took place in the maternity ward, and was carried out by trained midwives shortly after birth. This survey includes data extracted from the mother's medical records, the collection of biological samples, as well as face-to-face questionnaires with the mother, and includes 18,329 newborns. An in-depth telephone interview was conducted two months later: 15,536 mothers and 12,504 fathers responded to the full interview, collecting in-depth data on socio-economic status, family living arrangements, nutrition, and the environment that the children were growing up in. A new wave of interviews was carried out around the children's first birthday, with interviews of both parents ( $n=13,141$ mothers and 11,294 fathers), and including a similar, in-depth questionnaire to the previous wave. Follow-up waves took place at about two years, three and a half years and five and a half years after birth. We focus here on the twomonth wave (which we will refer to as wave 1) and the one-year data collection (wave 2).

Our analytical sample is made up of all households present at each wave studied that do not have missing information on the items used in the multiple deprivation indicators.

(2) This is to avoid overlap with a concurrent survey of very premature births.

Revue des politiques sociales et familiales $n^{\circ} 131-132-2^{\text {nd }}$ et $3^{\text {rd }}$ quarters 2019

177 Understanding children's well-being: A political issue 
This gives a sample of 12,020 households for wave 1 , and 12,895 for wave 2 . Had we selected one sample to cover both waves (i.e. households with no missing information at either wave), we would have obtained a small sample that was not nationally representative of either wave. Therefore, we chose two different samples, one per wave. This means that while we cannot directly compare analyses at wave 1 and wave 2, our analyses are nationally representative for children of those ages. Sample weights are applied to all analyses, this allows us to take account of the sampling design and attrition to ensure representative results.

\section{Methodology}

\section{Measuring deprivation}

To construct our measures of child deprivation, we draw on existing definitions and methodologies of multidimensional poverty (Bourguignon and Chakravarty, 2003; Alkire and Foster, 2011; Neubourg et al., 2013; Dickerson and Popli, 2015). The construction of the index relies on the identification of different dimensions of childhood deprivation that are important for young children. Unlike methods used for adults, we attempt to take into account all dimensions that matter in children's daily lives, not restricted to material deprivation. Notably, we include indicators relating to the parenting received by the child. Each dimension is composed of items identifying the lack of a specific good or activity, which we allow to vary over time to remain agerelevant, especially for parenting activities, which change significantly over the first year of life. Our strategy to identify potential items and dimensions is described in the next section. Due to data availability, we were not able to replicate all deprivation dimensions at both waves.

The living conditions of a child can be defined by variables $l_{i a j}$ that describe the attainment of the child $i$ at age a for the item $j$. The higher $l_{i a j}$, the more severe the deprivation. Items are dimension-specific and age-specific. For each item $l_{i a j}$, we define a threshold $z_{a j}$ and a binary variable $g_{i a j}$ indicating that the child is considered as deprived on this item if $l_{i a j}<z_{a j}$. Then, we define a score $c_{i a d}$ for each dimension $d$ counting the number of items from the child is considered to be deprived. For each dimension $d$, we define a threshold $\tilde{z}_{a d}$ and a binary variable $\delta_{i d a}$ indicating that the child is considered as deprived in the dimension $d$ if $c_{\text {iad }}>\widetilde{z}_{a d}$.

The identification of deprived children is based on a counting approach: we count the number of items of deprivation in each dimension. This approach imposes a dual cut-off methodology, in order to define: (1) deprivation for each item, and (2) deprivation for each dimension. This methodology is adapted from Marion Leturcq and Lidia Panico (2019), although unlike that paper, we do not construct an index of overall deprivation as we focus in this paper on the determinants of different dimensions of deprivation rather than an overall measure of deprivation. This methodology and the resulting indicators do not aim at comprehensively describing childhood deprivation in France in a representative manner, but at providing the best indicators for our research questions, given the available data.

\section{A description of the domains of childhood multi-domain deprivation}

The different items and dimensions of deprivation are presented in table 1. They include:

- material deprivation, which can be measured at wave 1 only, and aims at capturing the living conditions of the household. Items included describe whether the household cannot afford to: buy two pairs of shoes for each adult in the household, buy new clothes (not second hand), eat meat or fish every other day, pay bills on time, keep the home warm, replace furniture, go on holiday for at least one week a year, invite friends or family to the home at least once a month, and offer gifts at least once a year;

- housing deprivation, mostly includes housing-quality variables such as whether the home is damp, whether there is mould in the house, whether it is noisy, difficulty to heat, and overcrowded;

- extremely deprived living conditions indicates the lack of at least one key amenity in the child's home: e.g. no hot water, bathroom or toilets in the house;

- low parenting involvement: when the child is two months old, this dimension includes: rarely singing to the child, rarely talking to the child, having no skin-to-skin contact with the child, breastfeeding for less than one month. At the one-year wave, it includes mostly free activities such as singing to the child, playing with the child, reading books to the child, drawing with the child, but also parenting styles such as keeping calm when talking to the child, and having body contact in play with the child.

To select items and identify dimensions of deprivation, some normative choices have to be made. We first identify potential items that may measure the child's environment and child-centred deprivation. Variable

Revue des politiques sociales et familiales $n^{\circ} 131-132-2^{\text {nd }}$ et $3^{\text {rd }}$ quarters 2019 
selection is guided by data availability and the relevant literature. For material deprivation, we choose indicators that demonstrate a household's ability to afford key items that a majority of households in our sample possess (new clothes, shoes, at least two meals per day, enough heating - about $4 \%$ of households cannot afford each item); as well as normative social events and activities (inviting friends and family to the home, gifts), which most households carry out. About $4 \%$ of households cannot afford each of these activities; $16 \%$ to $19 \%$ of households cannot afford more expensive items such as at least one week of holidays a year, or being able to replace furniture. Not being able to afford several of these items or activities suggests deprived living conditions. Information for these items is available at wave 1 only (when the child is two months old).

Table 1 - List of indicators and definitions by dimensions of deprivation

\begin{tabular}{|c|c|c|c|c|}
\hline & Indicators & 2 Months (W1) & 1 Year (W2) & Definition and Cut-off \\
\hline \multirow[t]{10}{*}{ Material deprivation } & Affordability of new clothes & $4,6 \%$ & - & Cannot afford it \\
\hline & Affordability of 2 pairs of shoes per adult in the hh & $4,6 \%$ & - & Cannot afford it \\
\hline & Affordability of meat and fish every two days & $4,4 \%$ & - & Cannot afford it \\
\hline & Skipping at least one meal per day & $2,4 \%$ & - & Yes \\
\hline & Being able to pay bills on time & $8,6 \%$ & - & Cannot afford it \\
\hline & Being able to keep home warm & $3,9 \%$ & - & Cannot afford it \\
\hline & Affordability of replacing furniture & $16,6 \%$ & - & Cannot afford it \\
\hline & Affordability of one week's holidays & $19,1 \%$ & - & Cannot afford it \\
\hline & Inviting friends and family at home & $4,2 \%$ & - & Cannot afford it \\
\hline & Affordability of gifts at least once a year & $4,7 \%$ & - & Cannot afford it \\
\hline Total & & $17,5 \%$ & - & At last two items deprived \\
\hline \multirow[t]{5}{*}{ Housing deprivation } & Overcrowded housing & $18,8 \%$ & $19 \%$ & 1st quintile mpp didtribution \\
\hline & Difficult to heat the house (parents-reported) & $19,4 \%$ & $19,5 \%$ & yes \\
\hline & Damp in the house (parents-reported) & $8,2 \%$ & $8,3 \%$ & yes \\
\hline & Mould in the house (parents-reported) & $6,7 \%$ & $6,4 \%$ & yes \\
\hline & Noisy (parents-reported) & $11,7 \%$ & $11,5 \%$ & yes \\
\hline Total & & $15,8 \%$ & $15,8 \%$ & At least two items deprived \\
\hline \multirow[t]{3}{*}{ Extreme living conditions } & Hot water in the house & $1,1 \%$ & $1,0 \%$ & no \\
\hline & Bathroom in the house & $0,4 \%$ & $0,3 \%$ & no \\
\hline & Toilets in the house & $0,5 \%$ & $0,54 \%$ & no \\
\hline Total & & $1,6 \%$ & $1,6 \%$ & At least one item deprived \\
\hline \multirow[t]{9}{*}{ Parenting deprivation } & Parents sing songs to the child & $8,3 \%$ & $5,9 \%$ & Rarely \\
\hline & Parents talk to the child & $0,0 \%$ & - & Rarely \\
\hline & Parents keep calm while talking to the child & - & $2,8 \%$ & Rarely \\
\hline & $\begin{array}{l}\text { Parent have skin to skin contact } \\
\text { with child sometimes }\end{array}$ & $36,4 \%$ & - & no \\
\hline & Parents have body contact to play with the child & - & $1,2 \%$ & Rarely \\
\hline & Child breastfed less than 1 month & $49,3 \%$ & - & yes \\
\hline & Parents play with the child & - & $1,6 \%$ & Rarely \\
\hline & Parents read book to the child & - & $22,1 \%$ & Rarely \\
\hline & Parents draw with the child & - & $64,7 \%$ & Rarely \\
\hline Total & & $23,7 \%$ & $20,9 \%$ & At least two items deprived \\
\hline Monetary poverty & Household considered disposable income poor & $12.8 \%$ & $15,9 \%$ & $\begin{array}{l}50 \% \text { of the median of the } \\
\text { disposable income } \\
\text { distribution }\end{array}$ \\
\hline Total numbers of OBs & & 12020 & 12895 & \\
\hline
\end{tabular}

Source: ELFE, waves 2 months and 1 year.

Scope: Children born in continental France in 2011.

Interpretation: at wave 1, when the child is two months old, $4,6 \%$ of respondants declare they could not afford new clothes. At wave 1 , when the child is two months old, $17,5 \%$ of children are deprived on at least two items in the material dimension.

Revue des politiques sociales et familiales $n^{\circ} 131-132-2^{\text {nd }}$ et $3^{\text {rd }}$ quarters 2019 
For housing deprivation, we aimed at capturing housing quality (damp and mould in the house, noisy environment, difficulty to heat, overcrowding) - depending on the item, $7 \%$ to $19 \%$ of households are affected. We distinguish this dimension from extremely deprived housing conditions: we include here not having access within the dwelling to hot water, a bathroom, and toilets - for each these items, only $0,5 \%$ to $1 \%$ of households report not having access to these amenities. For parenting involvement, we chose variables describing activities and contact between the mother and the child (singing songs, skin-to-skin contact, etc.).

Second, we included these variables in a Multiple Component Analysis to explore which clusters of variables emerged and which items drove different axes. We carried out these analyses separately at each wave as we hypothesize that different clusters might emerge at different ages, and that the relative importance of each variable in driving axes might also differ according to child age. At this stage, we excluded variables that did not seem to drive any axis. Third, taking all retained items in the previous step, we identified discrete dimensions of deprivation, based on our own selection and the Multiple Component analyses; item composition at each age might vary. Different dimensions appeared at different ages: at wave 1, the items clustered into a material deprivation dimension, which did not appear at wave 2 . Finally, a dimension of parental involvement, grouping variables relating to parental activities and attachment, appeared. For each dimension, we define a cut-off indicating the number of items a child does not have above which that child is considered as deprived for that dimension. For each dimension (except for extreme living conditions), we consider that a child is deprived if the household does not have at least two items in this dimension. Therefore, as suggested by the literature, being deprived is defined by an accumulation of missing items: choosing one missing item only as a cut-off would not reflect the idea of accumulation of deprivation. On the contrary, choosing a higher cut-off of three missing items would mean only capturing a group of highly deprived households. For extreme living conditions, we choose a cut-off of one missing item as reasonable, as the items included in this dimension capture basic amenities, and therefore it can be argued that missing only one of these item already captures severe deprivation.

The monetary poverty indicator we propose is in line with previous literature. We consider equivalised disposable income as an indicator of the financial means available to the household. Disposable income corresponds to total household revenues net of housing costs, which allow us to control for heterogeneous housing costs across regions. In order to account for household composition, we use the OECD equivalence scales. Then, we consider as poor households whose equivalised income is $50 \%$ below the equivalent median disposable income in our survey population. It is therefore a measure of poverty relative to households with a child born in 2011, and not for all households in France.

Because Elfe is a household-based survey, we mostly focus on children's deprivation in the home (although the inclusion of parenting variables means that our measures are not just household deprivation indicators), and do not measure the deprivation they could experience within their neighbourhoods, or any other dimension not directly related to their home. While these are important dimensions of deprivation, as depicted by Urie Bronfenbrenner (1986) ecological systems theory, they are not fully explorable in our dataset.

\section{Regression approach}

Once our indicators are constructed, we use regression techniques to highlight which population groups are most vulnerable to monetary poverty and deprivation across several dimensions. Specifically, we assume the probability that a child will be deprived in a dimension $d$ at age $a$ can be written as:

$$
\operatorname{Pr}\left(y_{i a d} \mid x_{i a}\right)=\Lambda\left(\beta_{0 a d}+\beta_{1 a d} x_{1 a}+\cdots+\beta_{k a d} x_{k a}\right)
$$

where $y_{\text {iad }}$ is a binary variable indicating whether the child $i$ is considered deprived in dimension $d$ at age $a . x_{i a}$ is a vector of characteristics of the child at age a (or characteristics of the child's family). $\Lambda$ is the cumulative distribution function of a logistic function. The coefficients $\beta$ are age-specific and dimension-specific, so that we identify which groups are most vulnerable for each dimension $d$ at a given age $a$, allowing these groups to differ across ages and dimensions.

\section{Results \\ What proportion of children are classed as deprived?}

Table 1 presents the proportion of children deprived in each dimension and at each age. It shows that the proportion of children deprived in different dimensions does not change significantly between waves, even though each dimension is not always based on the same items nor on the same number of items. We identify $17,5 \%$ of households as materially deprived when the child is two months old. For 
housing conditions, we identify $15,8 \%$ of the households as deprived for each wave. For extreme housing conditions, $1,6 \%$ of households are identified as deprived at each wave. We identify $23,7 \%$ of children as deprived on the parenting dimension two months after birth, and 20,9\% at one year old. On the other hand, we classify $12,8 \%$ of

\begin{tabular}{|c|c|c|c|c|c|c|}
\hline \multirow[b]{4}{*}{ No deprivation } & \multicolumn{3}{|c|}{2 months } & \multicolumn{3}{|c|}{1 year } \\
\hline & \multirow[b]{3}{*}{$55 \%$} & \multicolumn{2}{|c|}{$\begin{array}{l}\text { Disposable } \\
\text { income poor }\end{array}$} & \multirow[b]{3}{*}{$67 \%$} & \multicolumn{2}{|c|}{$\begin{array}{c}\text { Disposable } \\
\text { income poo }\end{array}$} \\
\hline & & No & Yes & & No & Yes \\
\hline & & $94 \%$ & $6 \%$ & & $88 \%$ & $12 \%$ \\
\hline 1 dimension deprived & $33 \%$ & $85 \%$ & $15 \%$ & $28 \%$ & $79 \%$ & $21 \%$ \\
\hline 2 dimensions deprived & $10 \%$ & $65 \%$ & $35 \%$ & $5 \%$ & $62 \%$ & $38 \%$ \\
\hline 3 dimensions deprived & $2 \%$ & $58 \%$ & $42 \%$ & $<0,5 \%$ & . & . \\
\hline 4 dimensions deprived & $<0,5 \%$ & . & . & . & . & . \\
\hline Total & $100 \%$ & $87 \%$ & $13 \%$ & $100 \%$ & $84 \%$ & $16 \%$ \\
\hline
\end{tabular}

Source: ELFE, waves 2 months and 1 year.

Scope: Children born in continental France in 2011.

Interpretation: at two months, $55 \%$ of children are not classed as deprived. Among children deprived in 0 dimension, $94 \%$ are not income poor while $6 \%$ are classed as income poor.

Table 3 - Dimensions of cumulative deprivation, among children deprived on 2 dimensions or more

\begin{tabular}{|l|c|c|}
\hline Dimensions of deprivation & 2 months & 1 year \\
\hline Housing and Parenting & $39 \%$ & $83 \%$ \\
\hline Parenting and Material & $20 \%$ & $\cdot$ \\
\hline Housing and Extreme & $19 \%$ & $7 \%$ \\
\hline Extreme, Parenting and Material & $13 \%$ &. \\
\hline Housing, Extreme and Material & $3 \%$ & $\cdot$ \\
\hline Extreme and Parenting & $2 \%$ & $6 \%$ \\
\hline Housing, Extreme and Parenting &. & $4 \%$ \\
\hline Other combinations & $4 \%$ & $\cdot$ \\
\hline Total & $\mathbf{1 0 0} \%$ & $\mathbf{1 0 0} \%$ \\
\hline
\end{tabular}

Source: ELFE, waves 2 months and 1 year

Scope: Children deprived on at least of two dimensions, born in continental France in 2011 .

Interpretation: among children observed at two months and deprived on two dimensions or more, $39 \%$ are deprived on the housing dimension and on the parenting dimension. households observed at wave 1 and 15,9\% of households observed at wave 2 as monetary poor. Table 2 presents the cumulative aspect of deprivation. It shows that, at wave 1 , when children are 2 months old, $55 \%$ of children are not deprived in any dimension, $33 \%$ are deprived in one dimension only, and $10 \%$ are deprived in two dimensions. Approximatively $2 \%$ of children are classed as deprived in three or more dimensions of deprivation. At wave 2, when children are 1 year old, $67 \%$ are not deprived in any dimension. $28 \%$ are considered as deprived in one dimension only, and approximatively $5 \%$ are deprived in two dimensions or more. It is important to note that cumulating all dimensions of deprivation is very uncommon in the population of observed children, at both waves.

Table 3 provides more insight into the cumulative aspect of deprivation by showing for children deprived in at least two dimensions of deprivation, the most common combinations of dimensions of deprivation. At wave 1, 39\% of children cumulating two or more dimensions of deprivation were deprived in both the housing and parenting dimensions. $20 \%$ of them were deprived in both the material and parenting dimensions and $19 \%$ of them were deprived in the housing and extreme material dimensions. $13 \%$ were deprived in parenting, material and extreme material dimensions at the same time. At wave $2,83 \%$ of children deprived in two dimensions or more were deprived in housing and parenting dimensions. Other combinations include: housing and extreme material deprivation $(7 \%$ of children cumulated at least two forms of deprivation), and deprivation on extreme material and parenting dimensions $(6 \%)$. Other combinations were less common.

\section{Income poverty and deprivation:}

\section{two distinct measures of living conditions}

Table 4 explores the relationship between different dimensions of deprivation, and income poverty. Each cell in the

Table 4 - Overlap between income poverty and dimensions of deprivation

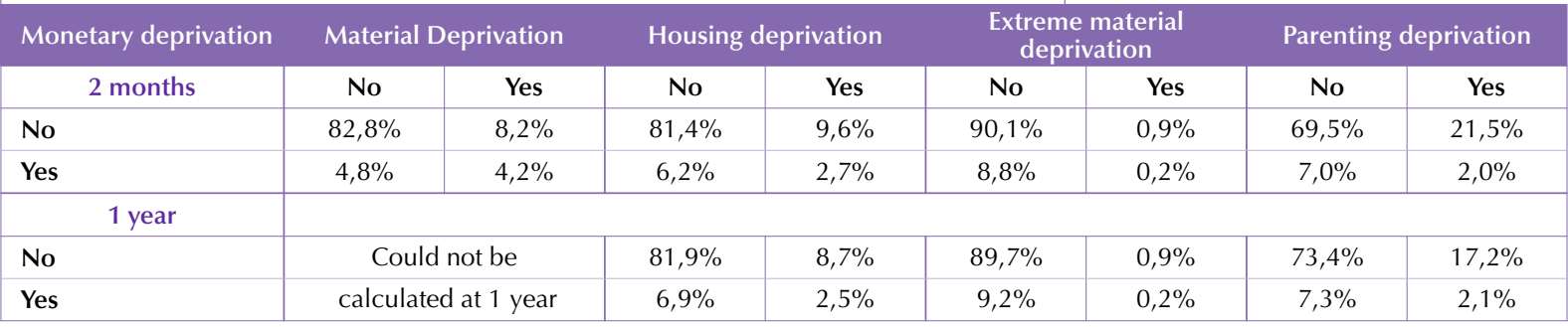

Source: ELFE, waves 2 months and 1 year.

Scope: Children born in continental France in 2011.

Interpretation: among children observed at two months, $82,8 \%$ are neither monetary poor nor materially deprived; $8,2 \%$ are materially deprived but not monetary poor; $4,8 \%$ are monetary poor but not materially deprived; and $4,2 \%$ are both monetary poor and materially deprived.

Revue des politiques sociales et familiales $n^{\circ} 131-132-2^{\text {nd }}$ et $3^{\text {rd }}$ quarters 2019 
table cross-tabulates children classed as income poor with each dimension of deprivation. At two months old, the largest overlap of income poverty is with material deprivation $(4,2 \%$ of children are both income poor and materially deprived). At both waves, the overlap between income poverty and other dimensions of deprivation is only slight: $2,7 \%$ of children are both income poor and housing deprived, and $2 \%$ of children are both income poor and receive low parenting involvement. Income poverty does not always overlap with deprivation. For example, when they are two months old, about $4,8 \%$ of income-poor children are not materially deprived. Conversely, about $8,2 \%$ of children are materially deprived but not income poor. For housing, 6,2\% of two-month-old children (and 6,9\% of one-year-olds) who are income poor are not deprived in the housing dimension, while $9,6 \%$ of two-month-olds are considered as housing deprived but not income poor ( $8,7 \%$ for one-year-olds). At both waves, $0,2 \%$ of children suffer both income poverty and extreme material deprivation, however $0,9 \%$ of children identified as deprived on the extreme material dimension are not classed as income poor. Deprivation on the parenting dimension shows an even smaller overlap: $21,5 \%$ of twomonth old children $(17,2 \%$ of one-year-olds) are both income poor and parenting deprived, and, for both waves, roughly $7 \%$ are income poor but not parenting deprived. Therefore, our measures of deprivation tend to capture different phenomena, distinct from income poverty.

Table 2 also provides some insights into the overlap between the different dimensions of deprivation and income poverty. Although the correlation between income poverty and the cumulative aspects of deprivation is clear, income poverty does not necessarily overlap with severe deprivation. At wave 1,94\% of infants who are not classed as deprived on any dimension of deprivation belong to a non-poor household, and $6 \%$ of them belong to an income poor household. Among children who are deprived in three dimensions or more, $58 \%$ are not considered as income poor, while $42 \%$ are considered as income poor. At wave $2,88 \%$ of children who are not deprived in any dimension belong to a non-poor household and $12 \%$ belong to an income-poor household. Among children who are considered as deprived in two dimensions or more, $62 \%$ would not normally be considered as income poor, while $38 \%$ would be.

In this analysis, we consider a household to be income poor if its disposable income is below a threshold set as $50 \%$ of the median income. The literature commonly uses a threshold of either $50 \%$ or $60 \%$ of the median income. Using a $50 \%$ of the median value threshold means that our poverty line is lower than one based on a $60 \%$ of the median income, which implies that we identify a smaller proportion of households as income poor. This choice is only likely to bias our results if the density of households between the $50 \%$ threshold and the $60 \%$ threshold is high, which is very unlikely, and if households belonging to this margin are very different in terms of their deprivation profile from households identified as poor using the $50 \%$ median threshold. This is very unlikely, given that in our sample deprivation and monetary poverty do not necessarily overlap.

\section{Who is deprived?}

For each wave and each dimension of deprivation, table 5 shows the characteristics of children classed as deprived in the different dimensions as compared to children who are not classed as deprived, as well as those classed as income poor compared to those not classed as income poor. Starting with the standard measure of poverty, our descriptive results show that, at wave 1 , households with no working parent, a parent from a migrant background, headed by a single parent, and low levels of parental education have higher income poverty rates. At the two months wave, families with a large number of co-resident children also appear to have high poverty rates, however we find smaller differences in the next wave.

Turning to deprivation, at wave 1 children classed as deprived in the housing or extreme living conditions dimensions are more likely to have: a parent who is not employed (around $51 \%$ of deprived children in these dimensions have a non-working mother, compared to $31,1 \%$ of mothers in the total sample; $21,5 \%$ of housing deprived children have a non-working father compared to $10,7 \%$ of fathers in the total sample), a parent with a migrant background ( $20 \%$ to $30 \%$ of children who are deprived in the housing, material or extreme housing conditions dimensions have a parent with a migrant background, whereas $10 \%$ to $11 \%$ of children have at least one migrant parent in the total sample): or a parent with lower educational qualifications (for roughly $50 \%$ of children classified as deprived in the housing, material or extreme housing conditions the highest level of parental education is high school or lower, against 32,5\% for all children). Housing deprived children are also more likely to live with their mother only $(9,2 \%$ against $5,5 \%$ for all children), and to have at least two siblings co-residing with them. This trend is reflected for the material deprivation dimension, 
Table 5 - Characteristics of children, according to deprivation status

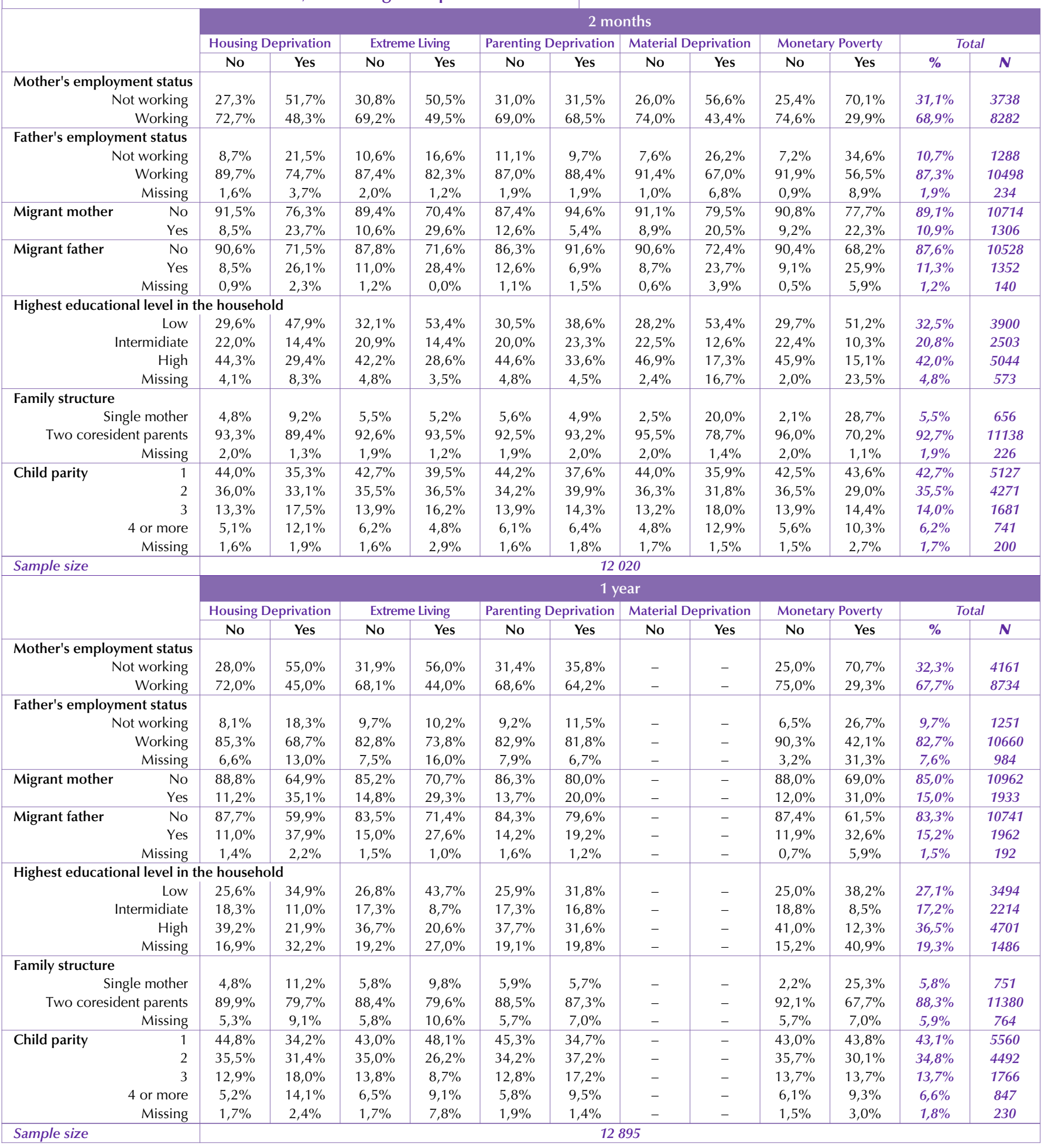

Source: ELFE, waves 2 months and 1 year.

Scope: children born in continental France in 2011.

Interpretation: for children observed at two months, among those who are not housing deprived, $27,3 \%$ have a non working mother, while among those who are housing deprived, $51,7 \%$ have a non working mother.

Revue des politiques sociales et familiales $n^{\circ} 131-132-2^{\text {nd }}$ et $3^{\text {rd }}$ quarters 2019

183 Understanding children's well-being: A political issue 
here we note that this dimension is particularly correlated with single parenthood ( $20 \%$ of materially deprived children live with their mother only), much more so than for housing-related dimensions.

Being classed as deprived on the parenting dimension at two months old is not correlated to parental employment or single parenthood, however children have a higher risk of being classed as deprived in this dimension when their parents have lower educational qualifications $(38,6 \%$ of children deprived in the parenting dimension live in a household in which the highest level of education is high school or lower, against 32,5\% in the whole sample). The association with migrant background is the opposite to that found with the previous deprivation dimensions: children whose parents did not have a migrant background are not more likely to be classed as deprived in the parenting sphere $(5,4 \%$ of children deprived in the parenting dimension have a migrant mother, $6,9 \%$ of them have a migrant father, whereas roughly $11 \%$ of children in our sample have a migrant parent). Finally, first-born children are less likely to be classed as deprived in this dimension.

Associations are very similar when we look at the one-year data. The only notable differences include a correlation between extremely deprived living conditions and single parenthood (which was not significant at the two-month wave), and a reversal of the association between parenting and migrant status: at one year, it is now children whose parents have a migrant background that are more likely to be deprived in this dimension, although this association is only slight. The association between parenting and education is still evident in the one-year-old data, but appears to be less strong than at the previous wave.

To confirm, which population groups are more likely to be classed as deprived,all things being equal, we use a logistic regression as described supra. Table 6 presents the odds-ratio from a logit regression estimating who is classed as income poor or deprived in each dimension, for each wave. The results largely confirm the analysis of the descriptive statistics, and allow us to understand better which characteristics drive the deprivation status. Notably, at wave 1, we find that higher parental educational attainment decreases the risk of being deprived, even as we control for other socio-demographic factors. While the impact is large for the risk of income poverty and material deprivation, it appears to be smaller for housing and extreme living conditions deprivation. Employment status of the parents has a particularly strong impact on monetary poverty. It has a smaller (but still significant) relationship with material and housing deprivation, but none with extreme living conditions or parenting, when all other socio-demographic factors are controlled for. As seen in the descriptive analyses, at two months old, parental migration status is linked to a higher risk of monetary, material, housing and extreme deprivation, but to a lower risk of parenting deprivation. Family structure has an extremely high correlation with monetary poverty (indicating a low variability in this group, i.e. most households classed as single-parent households are also classed as income poor). Unsurprisingly, this appears to translate into a very strong correlation with material deprivation. However, once all socio-demographic factors are controlled for, this group exhibits an increased risk of housing and extreme housing deprivation, as suggested by the descriptive analyses. We do not find an increased risk of parenting deprivation for this group.

Finally, child parity has no correlation with monetary poverty. However, the risk of housing deprivation increases with child parity. While first-born children are at lower risk of parenting and material deprivation, there is no further correlation between subsequent parities and these two dimensions of deprivation. At one year old, associations are largely similar. Notably differences with the two month data include the reversal of the association between migrant status and parenting (as already noted in descriptive statistics), and between family structure and parenting. Furthermore, the association between child parity and housing deprivation is now significant, while a more linear relationship with parenting is evident: when all other socio-demographic factors are controlled for, the higher the parity of the child, the higher the risk of being classed as deprived in this dimension.

\section{Conclusions}

Child poverty is an important item in many countries' political agendas, and rightly so: a vast body of work has shown the deleterious effects of experiencing poverty in childhood with a range of outcomes, both in childhood and later on in adulthood. In this paper, we make use of new, nationally representative data for children born in France in 2011 to draw a picture of who experiences poverty at birth and in the first year of life. This age group has been less considered in France, yet we know that the early years are important for understanding both future individual trajectories and the construction of populationlevel inequalities. Our rich data and multi-dimensional methods allow us to go further than simply using monetary 
poverty to capture children living in disadvantaged conditions. We construct four indicators of deprivation, and show that the overlap with monetary poverty exists but is not perfect: children can live in households not classed as income poor and still experience deprivation, and vice versa. These results call for a nuanced approach to childhood disadvantage, even in the early years, and highlight the need for policies that do not identify children living in deprived conditions based solely on household income.

Table 6 - Logit estimation, odds ratio of deprivation/poverty

\begin{tabular}{|c|c|c|c|c|c|c|c|c|c|}
\hline \multirow[b]{3}{*}{ Variables } & \multicolumn{5}{|c|}{2 months } & \multicolumn{4}{|c|}{1 year } \\
\hline & HD & ED & PD & MD & MD & HD & ED & PD & MP \\
\hline & (1) & (2) & (3) & (4) & (5) & (1) & (2) & (3) & (4) \\
\hline Highest education level in the household & & & & & & & & & \\
\hline Low & 1 & 1 & 1 & 1 & 1 & 1 & 1 & 1 & 1 \\
\hline Intermidiate & $\begin{array}{c}0,56^{* * *} \\
(0,04)\end{array}$ & $\begin{array}{c}0,56^{* * *} \\
(0,09)\end{array}$ & $\begin{array}{l}0,9 * * \\
(0,04)\end{array}$ & $\begin{array}{c}0,42^{* * *} \\
(0,02)\end{array}$ & $\begin{array}{c}0,49^{* * *} \\
(0,04)\end{array}$ & $\begin{array}{c}0,63^{* * *} \\
(0,05)\end{array}$ & $\begin{array}{c}0,46^{* * *} \\
(0,09)\end{array}$ & $\begin{array}{c}0,84^{* * *} \\
(0,04)\end{array}$ & $\begin{array}{c}0,58^{* * *} \\
(0,04)\end{array}$ \\
\hline High & $\begin{array}{c}0,55^{* * *} \\
(0,03)\end{array}$ & $\begin{array}{c}0,52^{* * *} \\
(0,08)\end{array}$ & $\begin{array}{c}0,62^{* * *} \\
(0,02)\end{array}$ & $\begin{array}{c}0,26 * * * \\
(0,01)\end{array}$ & $\begin{array}{c}0,34 * * * \\
(0,02)\end{array}$ & $\begin{array}{c}0,57^{* * *} \\
(0,02)\end{array}$ & $\begin{array}{c}0,49^{* * *} \\
(0,07)\end{array}$ & $\begin{array}{c}0,71^{* * *} \\
(0,03)\end{array}$ & $\begin{array}{c}0,37^{* * *} \\
(0,02)\end{array}$ \\
\hline Missing & $\begin{array}{c}1,16 \\
(0,19)\end{array}$ & $\begin{array}{c}0,36^{*} \\
(0,2)\end{array}$ & $\begin{array}{l}1,15 \\
(0,2)\end{array}$ & $\begin{array}{c}0,93 \\
(0,15)\end{array}$ & $\begin{array}{c}0,73 \\
(0,16)\end{array}$ & $\begin{array}{l}1,10^{*} \\
(0,06)\end{array}$ & $\begin{array}{c}0,72^{* *} \\
(0,1)\end{array}$ & $\begin{array}{c}0,78^{* * *} \\
(0,04)\end{array}$ & $\begin{array}{l}0,89^{*} \\
(0,05)\end{array}$ \\
\hline Household's employment status & & & & & & & & & \\
\hline Employed parents & 1 & 1 & 1 & 1 & 1 & 1 & 1 & 1 & 1 \\
\hline At least one unemployed parent & $\begin{array}{c}2,05^{* * *} \\
(0,093)\end{array}$ & $\begin{array}{c}1,28 \\
(0,21)\end{array}$ & $\begin{array}{l}0,95 \\
(0,3)\end{array}$ & $\begin{array}{c}2,47^{* * *} \\
(0,11)\end{array}$ & $\begin{array}{c}4,37^{* * *} \\
(0,22)\end{array}$ & $\begin{array}{c}2,02 * * * \\
(0,08)\end{array}$ & $\begin{array}{c}1,77^{* * *} \\
(0,21)\end{array}$ & $\begin{array}{c}1,02 \\
(0,03)\end{array}$ & $\begin{array}{l}5,6^{* * *} \\
(0,27)\end{array}$ \\
\hline Missing & - & - & - & - & - & & & & \\
\hline Household's migrant status & & & & & & & & & \\
\hline Rest of population & 1 & 1 & 1 & 1 & 1 & 1 & 1 & 1 & 1 \\
\hline At least one migrant parent & $\begin{array}{l}2,7^{* * *} \\
(0,12)\end{array}$ & $\begin{array}{c}2,55^{* * *} \\
(0,28)\end{array}$ & $\begin{array}{c}0,46^{* * *} \\
(0,02)\end{array}$ & $\begin{array}{c}2,33^{* * *} \\
(0,13)\end{array}$ & $\begin{array}{c}3,11^{* * *} \\
(0,19)\end{array}$ & $\begin{array}{c}3,35^{* * *} \\
(0,15)\end{array}$ & $\begin{array}{c}1,68^{* * *} \\
(0,19)\end{array}$ & $\begin{array}{c}1,38^{* * *} \\
(0,06)\end{array}$ & $\begin{array}{c}2,62^{* * *} \\
(0,15)\end{array}$ \\
\hline Missing & - & - & - & - & - & & & & \\
\hline Family structure & & & & & & & & & \\
\hline Two coresident parents & 1 & 1 & 1 & 1 & 1 & 1 & 1 & 1 & 1 \\
\hline Single mother & $\begin{array}{c}0,94 \\
(0,16)\end{array}$ & $\begin{array}{c}1,08 \\
(0,44)\end{array}$ & $\begin{array}{c}0,68^{* *} \\
(0,11)\end{array}$ & $\begin{array}{c}4,69^{* * *} \\
(0,70)\end{array}$ & $\begin{array}{c}15,06^{* * *} \\
(3,25)\end{array}$ & $\begin{array}{c}1,36^{* * *} \\
(0,12)\end{array}$ & $\begin{array}{c}1,04 \\
(0,19)\end{array}$ & $\begin{array}{c}0,94 \\
(0,09)\end{array}$ & $\begin{array}{c}11,93^{* * *} \\
(1,28)\end{array}$ \\
\hline Missing & $\begin{array}{c}0,83 \\
(0,13)\end{array}$ & $\begin{array}{c}0,69 \\
(0,22)\end{array}$ & $\begin{array}{c}1,04 \\
(0,09)\end{array}$ & $\begin{array}{c}0,94 \\
(0,14)\end{array}$ & $\begin{array}{c}0,77^{* *} \\
(0,09)\end{array}$ & $\begin{array}{c}1,02 \\
(0,08)\end{array}$ & $\begin{array}{c}1,57^{* *} \\
(0,33)\end{array}$ & $\begin{array}{c}1,20^{* *} \\
(0,09)\end{array}$ & $\begin{array}{c}0,79^{* *} \\
(0,07)\end{array}$ \\
\hline Child parity & & & & & & & & & \\
\hline 1 & 1 & 1 & 1 & 1 & 1 & 1 & 1 & 1 & 1 \\
\hline 2 & $\begin{array}{c}1,3 * * * \\
(0,06)\end{array}$ & $\begin{array}{l}1,23 \\
(0,2)\end{array}$ & $\begin{array}{l}1,4^{* * *} \\
(0,05)\end{array}$ & $\begin{array}{c}1,25^{* * *} \\
(0,07)\end{array}$ & $\begin{array}{c}1,05 \\
(0,06)\end{array}$ & $\begin{array}{c}1,32^{* * *} \\
(0,12)\end{array}$ & $\begin{array}{l}0,78^{*} \\
(0,10)\end{array}$ & $\begin{array}{c}1,41^{* * *} \\
(0,05)\end{array}$ & $\begin{array}{l}1,11^{*} \\
(0,06)\end{array}$ \\
\hline 3 & $\begin{array}{c}1,49^{* * *} \\
(0,09)\end{array}$ & $\begin{array}{l}1,13 \\
(0,2)\end{array}$ & $\begin{array}{c}1,29 * * * \\
(0,08)\end{array}$ & $\begin{array}{c}1,43^{* * *} \\
(0,1)\end{array}$ & $\begin{array}{c}1,01 \\
(0,08)\end{array}$ & $\begin{array}{c}1,59 \text { *** } \\
(0,11)\end{array}$ & $\begin{array}{c}0,55 \\
(0,09)\end{array}$ & $\begin{array}{c}1,64 * * * \\
(0,09)\end{array}$ & $\begin{array}{c}0,87 \\
(0,08)\end{array}$ \\
\hline$\geq 4$ & $\begin{array}{c}2,15^{* * *} \\
(0,2)\end{array}$ & $\begin{array}{c}0,74 \\
(0,22)\end{array}$ & $\begin{array}{c}1,39 * * * \\
(0,12)\end{array}$ & $\begin{array}{c}1,96^{* * * *} \\
(0,18)\end{array}$ & $\begin{array}{c}1,25 \\
(0,23)\end{array}$ & $\begin{array}{c}2,51^{* * * *} \\
(0,18)\end{array}$ & $\begin{array}{c}0,92 \\
(0,21)\end{array}$ & $\begin{array}{c}1,97^{* * *} \\
(0,14)\end{array}$ & $\begin{array}{c}0,85 \\
(0,08)\end{array}$ \\
\hline Missing & $\begin{array}{c}1,14^{* * *} \\
(0,15)\end{array}$ & $\begin{array}{c}0,20^{* * *} \\
(0,07)\end{array}$ & $\begin{array}{c}1,45^{* * *} \\
(0,2)\end{array}$ & $\begin{array}{c}0,99 \\
(0,19)\end{array}$ & $\begin{array}{c}2,11 * * * \\
(0,59)\end{array}$ & $\begin{array}{c}1,83^{* * *} \\
(0,20)\end{array}$ & $\begin{array}{c}4,09 * * * \\
(0,97)\end{array}$ & $\begin{array}{c}0,94 \\
(0,10)\end{array}$ & $\begin{array}{c}1,95^{* * *} \\
(0,38)\end{array}$ \\
\hline Controls & YES & YES & YES & YES & YES & YES & YES & YES & YES \\
\hline$N$ & 12020 & 12020 & 12020 & 12020 & 12020 & 12895 & 12895 & 12895 & 12895 \\
\hline
\end{tabular}

Source: ELFE, waves 2 months and 1 year. Scope: children born in continental France in 2011

HD: Housing deprivation; ED: Extreme living conditions; PD: Parenting deprivation; MD: Material deprivation; MP: Monetary poverty.*** refers to $1 \%$ significance. Control variables: mother's age, child sex, period of birth. 
Our results highlight a number of population groups that might be most at risk of experiencing poverty and deprivation from birth. As our dimensions of deprivation capture different aspects of children's lives, it is normal that the characteristics of children at risk of being deprived vary across dimensions. The risk of being monetary poor is highly correlated to the family status and employment status of parents, while parental deprivation is mostly related to the rank of the child, but not to family status or parental employment. Housing deprivation and monetary deprivation are driven by almost the same characteristics, but education, family structure, and parental employment are much more strongly correlated to monetary poverty than housing deprivation. This perhaps suggests a role of social policies in moderating some of the negative impacts of income poverty on living conditions, but not for all groups: housing deprivation was more strongly correlated to parental migrant status and child parity, suggesting that migrant households and large families struggle to access quality housing. While some of these results are expected, considering a number of population characteristics as well as several domains of deprivation allowed us to provide a more nuanced picture of who experiences deprivation and how. For example, single motherhood has opposite effects on different dimensions of deprivation. It is not related to housing deprivation (perhaps due to housing policies that help single parents access relatively good quality social housing), but is very strongly correlated to material deprivation and monetary poverty. This group has a lower risk of deprivation in the parenting dimension two months after birth, but that risk is reversed by the child's first birthday. Another interesting group is that of large families, who are more deprived on a number of indicators such as housing and parenting, even after we control for other socio-demographic factors. Their deprivation is therefore not due to their migrant or educational background. These analyses therefore suggest that "deprived" groups are not homogeneous, and different groups will need different types of policies to best support them.

While our analyses have a number of strengths, they should be interpreted within their limits. First, these measures, as commonly acknowledged in the literature, are based on data availability and on country-specific norms of what is considered as a "basic" need for children. Therefore, these measures are not easily comparable to those based on other datasets or other countries and do not lend themselves well to international comparisons. Second, because of data availability, we are not able to construct dimensions of poverty that are fully comparable across time. Therefore, these measures do not lend themselves well to longitudinal analyses such as studying changes in poverty and deprivation among individuals [Panico and Leturcq, (2019), for possible methods with similar data].

To conclude, using recent, national-representative data for France, we have described the living conditions of children around birth and in the first year of life. Using both a classic approach (measuring financial poverty) and a multi-domain deprivation framework, we show that poverty and disadvantaged conditions are not uncommon at the starting gate for infants living in France. Altogether, our results suggest that poverty and deprivation at birth are multi-faceted concepts that do not affect all population groups in the same manner, calling for public policies that do not take a "one size fits all" approach to combat childhood poverty. 
- Alkire S., Foster J., 2011, Counting and multidimensional poverty measurement, Journal of Public Economics, vol. 95, n 7, p. 476-487.

- Bourguignon F., Chakravarty S. R., 2003, The measurement of multidimensional poverty, The Journal of Economic Inequality, vol. 1, $\mathrm{n}^{\circ}$ 1, p. 25-49.

- Bronfenbrenner U., 1986, Ecology of the family as a context for human development: Research perspectives, Developmental psychology, vol. 22, n 6, p. 723.

- Case A., Fertig A., Paxson C., 2005, From cradle to grave? The lasting impact of childhood health and circumstance, Journal of Health Economics, vol. 24, n 2, p. 365-389.

- Charles M.-A., Leridon H., Dargent P., Geay B., \& the Elfe team, 2011, Tracking the lives of 20,000 children - Launch of the Elfe child cohort study, Populations and Societies, $\mathrm{n}^{\circ} 475$.

- Conger R. D., Conger K. J., Martin M. J., 2010, Socioeconomic status, family processes, and individual development, Journal of Marriage and Family, vol. 72, n³, p. 685-704.

- Dahl G. B., Lochner L., 2012, The impact of family income on child achievement: Evidence from the earned income tax credit, American Economic Review, n 102, p. 1927-1956.

- Dickerson A. P., Popli G., 2015, The many dimensions of child poverty: Evidence from the UK Millennium Cohort Study, The Sheffield Economic Research Paper Series (Serps), Department of Economics, University of Sheffield.

- Dong M., Giles W. H., Felitti V. J., Dube S. R., Williams J. E., Chapman D. P., Anda R. F., 2004, Insights into causal pathways for ischemic heart disease: Adverse Childhood Experiences study, Circulation, vol. 110, n 13, p. 1761-1766.

- Duncan G. J., Magnuson K., Kalil A., Ziol-Guest K., 2012, The importance of early childhood poverty, Social Indicators Research, vol. 108, $\mathrm{n}^{\circ} 1$, p. 87-98.

- Duncan G. J., Magnuson K., 2013, The long reach of early childhood poverty, Research and Policy Challenges, in Jean Yeung W.-Y., Yap M.-T. (eds), Economic stress, human capital, and families in Asia, Dordrecht, Springer, p. 57-70.

- Ermisch J., Jäntti M., Smeeding T., (eds), 2012), From parents to children: The intergenerational transmission of advantage, New York, Russell Sage Foundation.

- Esping-Andersen G., 2008, Childhood investments and skill formation, International Tax and Public Finance, vol. 15, $\mathrm{n}^{\circ} 1$, p. 19-44.

- Fusco A., Guio A. C., Marlier E., 2011, Income poverty and material deprivation in European countries, Technical report, Luxemburg: Liser.

- Gallo V., Mackenbach J. P., Ezzati M., and all, 2012, Social inequalities and mortality in Europe - results from a large multi-national cohort, PLoS One, vol. 7, n 7, p. e39013.

- Haut Conseil de la famille, de l'enfance et de l'âge (HCFEA), 2018, Lutter contre la pauvreté des familles et des enfants : constats et propositions du HCFEA - Note de synthèse, Report adopted by the Conseil de la famille on 5th June 2018.

- Irwin L. G., Siddiqi A., Hertzman G., 2007, Early child development: A powerful equalizer. Vancouver, BC, Canada, Human Early Learning Partnership (HELP).

- Johnson R. C., Schoeni R. F., 2011, The Influence of early-life events on human capital, health status, and labor market outcomes over the life course, Journal of Economic Analysis and Policy, vol. 611, n 3, p. 2521.

- Juillard H., Thierry X., Razafindratsima N., Bringe A., Lanoë J. L., 2016, Pondérations de l'enquête Elfe en maternité. Retrieved from https://pandora.vjf.inserm.fr/public/docs/ELFE_NoteDet0.pdf.

- Leturcq M., Panico L., 2019, The long-term effects of parental separation on childhood multidimensional deprivation: A lifecouse approach, Social Indicators Research, p. 1-34. http://hdl.handle.net/20.500.12204/ AWhvuwJ-XMQCvuZmm7MV.

Revue des politiques sociales et familiales $n^{\circ} 131-132-2^{\text {nd }}$ et $3^{\text {rd }}$ quarters 2019

$187 \quad$ Le bien-être des enfants : un enjeu politique 
- Levine P. B., 2011, How does parental unemployment affect children's educational performance? In Duncan G. J., Murnane R. (eds.), Whither opportunity? Rising inequality and the uncertain life chances of low-income children, New York, NY, Russell Sage Foundation, p. 315-335.

- Observatoire des inégalités et Compas (CIC), 2018, Rapport sur la pauvreté en France, Observatoire des inégalités et Compas, Tours, éditions Observatoire des inégalités.

- Neubourg C. (de), Chai J., Milliano M. (de), Plavgo I., 2013, Cross-country MODA study: Multiple Overlapping Deprivation Analysis (MODA), Technical Note, Innocenti Working Papers $\mathrm{n}^{\circ}$ 2012-05, Florence, Unicef Office of Research.

- Pearce A., Lewis H., Law C., 2013, The role of poverty in explaining health variations in 7-year-old children from different family structures: Findings from the UK Millennium Cohort Study, Journal of epidemiology and community health, vol. 67, $\mathrm{n}^{\circ} 2$, p. 181-189.

- Sen A.,1999, Commodities and capabilities, New Delhi, Oxford University Press India.

- Stiglitz J., Sen A., Fitoussi J. P., 2009, The measurement of economic performance and social progress revisited, Reflections and overview, Commission on the Measurement of Economic Performance and Social Progress. http://www.stiglitz-sen-fitoussi.fr/documents/overview-eng.pdf.

- Townsend P., 1979, Poverty in the United Kingdom: A survey of household resources and standards of living, Berkeley, CA: University of California Press.

- Unicef Office of Research, 2014, Children of the Recession: The impact of the economic crisis on child well-being in rich countries, Innocenti Report Card 12, Florence, Unicef Office of Research.

- Unicef Office of Research, 2013, Child well-being in rich countries: A comparative overview, Innocenti Report Card 11, Florence, Unicef Office of Research. 